\title{
Kingella denitrificans
}

National Cancer Institute

\section{Source}

National Cancer Institute. Kingella denitrificans. NCI Thesaurus. Code C86450.

A species of aerobic, Gram negative, rod or cocci shaped bacteria assigned to the phylum Proteobacteria. This species is nonmotile, oxidase positive and ferments glucose, although the latter characteristic may disappear upon continuous subcultivation. K. dentrificans is a commensal org anism found in the upper respiratory tract and while it is thought to be mostly nonpathogenic, it has been associated with at least one case of infective endocarditis. 